\title{
Exocyst Complex Component 7
}

National Cancer Institute

\section{Source}

National Cancer Institute. Exocyst Complex Component 7. NCI Thesaurus. Code

C113129.

Exocyst complex component 7 (735 aa, $23 \mathrm{kDa})$ is encoded by the human EXOC7 gene.

This protein is involved in the regulation of exocytosis. 